\title{
AIDS registration becoming a political issue in Germany $t^{102}$
}

\section{Hamburg}

THE control of AIDS (acquired immune deficiency syndrome) is gaining political momentum daily and is now generating as much public anxiety as unemployment, foreign affairs, environment and tax. In the wake of last month's general election, the winners - the Christian Democrats $(\mathrm{CDU})$, their sister party CSU and the Liberals (FDP) - have been negotiating to install a new Christian-Liberal coalition and have witnessed AIDS gaining political stature. Compulsory registration of AIDS victims is now a prime issue.

Franz-Josef Strauss, Minister President of the state of Bavaria and head of the CSU, has asked his partners to discuss the epidemiological aspect of the disease. $\mathrm{He}$ and his party demand a compulsory registration for all who are infected with human immunodeficiency viruses - similar to the strategy adopted in Sweden.
Newspapers daily report the disease in big headlines, mentioning new cases and speculating on the chances of infection. AIDS had been ignored for a long time by West German politicians. The Health Committee of the Bundestag (parliament) was briefed for the first time in autumn 1985 . One year on, the first plenary discussion took place; it lasted only half an hour. The result was a commitment to research and public information.

The Minister of Health, Heiner Geissler, did almost nothing about AIDS during his period in the Cabinet. His successor, the Christian Democrat Rita Süssmuth, who came into office in September 1985, did not share Geissler's opinion that AIDS was a problem only of the high-risk groups. Her ministry started a campaign of enlightment, paying millions of marks for advertising in newspapers and magazines, television, folders and

\section{MRC pushing for government funds for AIDS vaccine research}

\section{London}

Wiтн an annual budget that would soon be $£ 10$ million, it would be possible to organize and direct an effective AIDS (acquired immune deficiency syndrome) vaccine research programme in the United Kingdom.

The claim is that of the Medical Research Council (MRC) which has devised the blueprint of such a plan, currently being studied by government. The disclosure was made last week to the House of Commons Social Services Committee as it took evidence from the MRC on AIDS.

The plan, submitted to government through Mr Kenneth Baker, Minister for Education and Science, at the end of December, outlines a strategy that will give the council extra AIDS funding of $£ 2.5$ million in the first year, rising to $£ 4-6$ million in the second and then $£ 10$ million before the fifth year.

In the written evidence to the committee the MRC had claimed: "We believe that the UK has the scientific capability for making a decisive contribution to the development of an AIDS vaccine provided that a political lead is given and that substantial extra funding, outside the Science Vote, is forthcoming. A number of distinguished scientists in the UK have expressed a wish to take part in a programme of research to develop an AIDS vaccine."

The paper, supplemented by oral evidence principally from Lord Jellicoe and Sir James Gowans, paints a grim picture.
To determine the behaviour of the disease, groups of infected individuals need to be studied for another 20 years or more, concludes the MRC. But a new British programme to find a vaccine should be mounted and the MRC would speedily allocate the funds through its mechanisms for 'special project grants'.

The MRC, which created a working party on AIDS about 4 years ago, has since provided eight special grants for AIDS research from its own funds and has diverted resources at its own establishment, the Clinical Research Centre at a total cost of $£ 700,000$ a year. Also seven 'special allocations' have been made for epidemiological studies, funded by the health departments to the tune of $£ 300,000$ a year.

The council was recently awarded an extra $£ 1$ million a year to pay for further AIDS research. Additional research in Africa, where the MRC already supports projects in The Gambia and Zambia, is now also expected to be financed.

The MRC evidence emphasized that general screening of the population for human immunodeficiency virus infection raises difficult ethical and legal questions. But it concludes that: "There is a need now both for extensive facilities for the voluntary testing of all sexually active members of the population who are willing to know if they are infected, and the testing of representative samples of the population to monitor the spread of infection".

\section{DER SPIFEEL}

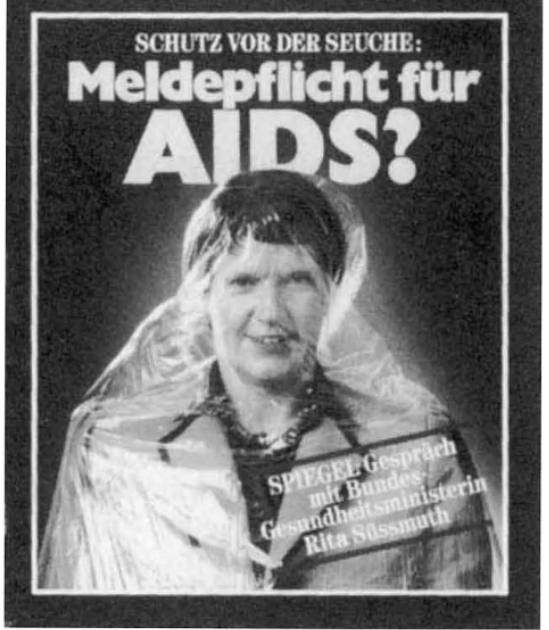

posters. A current youth centre poster declares "Carnival will be over on Ash Wednesday, AIDS won't".

Süssmuth is an enthusiastic proponent of the use of condoms - she was photographed for the magazine Der Spiegel in a huge plastic bag. Her campaign is supported by the Liberals, Social Democrats and Greens. She rejects, however, compulsory registration, at least at the moment. Her political influence will very much depend on the success of her campaign. In Berlin the campaign has considerably reduced the number of cases of venereal disease. At the end of January there were 875 individuals in West Germany registered with AIDS, out of whom 409 have already died. Süssmuth estimates that the number of infected persons lies between 30,000 and 100,000 and that by 1990 half a million West Germans will have the virus.

CSU health expert Kurt Falthauser wrote a paper for the CSU members of parliament in Bonn in which he demanded compulsory AIDS tests for risk groups such as haemophiliacs, drug addicts and registered prostitutes, as well as for all pregnant women and for travellers and foreigners from "risk countries". A voluntary test (anonymous and free of costs) is also to be offered to every resident of West Germany.

At a later stage, the CSU expert recommends "compulsory tests and registration for the whole population", for which the preparations must be made now. Friedrich Zimmermann, CSU Minister of the Interior, even considers restrictions on infected persons. CSU MP Erich Riodl demands the separation of groups in places where people have to live together such as schools, clubs and factories.

The Liberals also demand an 'AIDS ministry'. Part of the Süssmuth Ministry and parts of the Ministry of Labour should be put together to create a new Health Ministry, which could better cope with the growing problem. 